\title{
Caught in the Current: A Self-Study of State-Mandated Compliance in a Teacher Education Program
}

\author{
JOHN KORNFELD \\ KAREN GRADY \\ PERRY M. MARKER \\ MARTHA RAPP RUDDELL
}

\author{
Sonoma State University
}

Background/Context: The nationwide preoccupation with accountability continues to grow, with teacher credentialing programs facing growing scrutiny through state-mandated accountability systems. In response to Senate Bill 2042 passed by the California state legislature in 1998, the California Commission for Teacher Credentialing (CCTC) established new standards to which all credentialing institutions in the state must comply.

Implementing credential programs aligned to the new standards could have an enormous impact on teacher education in California. The way we use language in particular contexts not only represents perspectives, but creates them as well. Therefore, California's new teacher education standards, replete with their highly prescriptive language, could conceivably result in a new standardization of the way teacher educators conceptualize and implement programs throughout the state.

Focus of Study: The authors examine the impact of California's state-mandated revision of teacher education programs on their department's—as well as on individual faculty members'approach to teacher education. They explore the extent to which faculty were able to uphold their department's ideals of a progressive, learner-centered teacher education program-in spite of the state's stringent new requirements.

Setting: The research took place in the secondary teacher education department at a California State University.

Participants: The participants were all ten full-time faculty members in the department at the time of the program revision. 
Research Design: In this qualitative self-study, the authors conducted and analyzed interviews with department members, and analyzed discussions in department meetings, program documents, and conversations (formal and informal) among the authors themselves. Drawing from critical discourse theory, the authors investigate the ways that the discursive practices in state regulations governing teacher education variously positioned members of the department, making particular teacher educator subjectivities available, and examine how faculty members both adopted and resisted these subjectivities as the department developed and implemented the new state-required program.

Findings: In spite of claims by faculty that the standardization process had little impact on their approach to teaching, the authors' analysis of interview and conversational data and documents suggests otherwise. Faculty members' increased use of technocratic language and terminology reflecting compliance with the new state standards reveals a substantive shift in the ways they think about what they do.

Conclusions: The authors argue that no one should assume he or she is immune to the effects of top-down standardization; but they note that this type of self-study process can enable faculty to realign their actions with their beliefs, to regain control of their discourse and of their identities as teacher educators.

\section{BACKGROUND AND PURPOSE OF THE STUDY}

In the spring of 2002, department faculty at our California university were directed to revise our secondary teaching credential program to meet new state-mandated standards for teacher education. This qualitative self-study examines the extent to which developing and implementing the revised program has affected our approach-individually and as a group-to teacher education. How, we asked, are we being affected by our participation in this state-required program? As we work with each other and our students, to what extent are we remaining true to our ideals about teacher education? How is preparing our students to meet the required standards affecting the way we think about teacher education? Is there a disparity between what we say we believe and what we do in practice?

\section{CAUGHT IN THE GURRENT OF LEGISLATED EXCELLENCE}

The nationwide preoccupation with public school accountability continues to grow, with teachers and administrators pressured to structure curricula around state-mandated standards assessed by high-stakes tests. Credentialing programs in schools of education also face growing scrutiny through state-mandated accountability systems. In response to Senate Bill 2042 passed by the California state legislature in 1998, the California Commission for Teacher Credentialing (CCTC) established 
new standards to which all credentialing institutions in the state must comply. The document entitled Standards of Quality and Effectiveness for Professional Teacher Preparation Programs (2001) consists of 19 standards, each of which includes a number of specific elements. In order to win the CCTC's approval, institutions must submit lengthy documents detailing how their proposed credential programs will meet each element of each standard-128 elements in all. In order to earn their credentials in the new program, candidates have to demonstrate their knowledge of 13 Teaching Performance Expectations (TPEs), which are embedded in the 19 standards, by passing a high-stakes Teaching Performance Assessment (TPA). This assessment involves four major tasks, each with carefully scripted and meticulously detailed instructions. For example, Task 3 (Classroom Assessment of Academic Learning Goals) entails six stepsincluding selecting and planning an assessment, observing and assessing individual students and a whole class, and analyzing and reflecting on the assessment - and requires candidates to respond in writing to more than 50 separate prompts.

The state-sanctioned view of learning as the mastery of discrete skills independent of context and individual differences has been codified in law and realized in regulations. At the same time that California fourthgraders labor to read one-half million words annually (California State Board of Education,1997) and their teachers worry about preparing them for the onslaught of spring testing, teacher candidates also labor to embody a set of atomized standards and secondary teacher educators worry about candidates in all content areas having to master such standards as "teaching organized, systematic, explicit skills that promote fluent reading, including decoding skills and spelling patterns" (Standard $7 \mathrm{~B}[\mathrm{c}][\mathrm{ii}])$.

This latest development in the CCTC's regulation of teacher education in California seems to be the next level of what Wood (1992) calls the "legislated excellence movement." During the 1990s, the California legislature and CCTC implemented increasingly stringent accountability measures to ensure that teachers would teach the subject area standards in their classrooms; now the focus is widening to include teacher preparation institutions. Controlling the actions of teachers at all levels in publicly funded institutions is couched in the language of student achievement so that such efforts appear beyond reproach. As Toch (2000, p. 295) argues, the "teacher training (sic) issue" must be addressed by government overseers: "Students cannot be expected to master today's higher standards without having teachers capable of teaching the higher standards. It's that simple."

Implementing credential programs aligned to the new standards and 
devoting the time necessary to prepare candidates to pass the TPAs could have an enormous impact on teacher education in California-which is, of course, exactly what the legislature anticipated when it passed SB 2042. Gee (1996) and Luke (1997) argue that the ways in which discourses are taken up among members of a community are constitutive of ways of being in that community. As Gee (1996) notes, the way we use language in particular contexts not only represents perspectives, but creates them as well. Therefore, just as detailed curriculum guidelines in California have served to standardize instruction over the past decade in most school districts, our new teacher education Standards of Quality and Effectiveness (2001), replete with the kind of prescriptive language quoted above (Standard 7B[c] [ii]), could conceivably result in a new standardization of the way we conceptualize and implement teacher education programs throughout the state. Discourses also serve ideological and material interests in asymmetrical power relations that create and sustain differential access to what Gee (1996) calls "social goods." If the social goods relevant to a teacher education program include such rewards as candidates having access to a local credential program, the continued existence of our School of Education, and our own employment, then the new discourse of teacher education regulations serves as a material resource for teacher education faculty and candidates alike to exchange for accreditation and certification.

Thus, former Secretary of Education Rod Paige's vision (2002, p. 710) for No Child Left Behind crystallizes the potential impact of SB 2042 and the new standards: "A river that had wandered sluggishly east suddenly shifted and began to flow west. . . . The new westward current will flow swiftly, and it will carry everyone along. Boats that had run aground or been snagged in the shallows will be shaken loose and brought back to midstream." The new standards and the language used to enumerate them could serve to sustain and legitimize the unequal power relations between the State and its credentialing institutions, so that all credentialing programs-and those who teach in them-flow together down this river, willingly or not.

Teacher educators have reacted vehemently to the new standards and TPAs. Sleeter (2003) declares, "I am outraged [that] ... the state has simply announced that there is now consensus around what young people should know. Further I am outraged that the state, through SB 2042, has configured the role of teachers and teacher educators as deliverers of that knowledge." Teacher educators decry both the corporatization of schools of education (Berlak, 2003; Marker, 2003) and the anti-intellectualism inherent in the standards (Sleeter, 2003). For example, one of the elements in Standard 1, Program Design, calls for each candidate to 
learn how to teach the content of the standards to all students using stateadopted materials and assessing students in relationship to the scope and sequence of the standards. Primacy is given to using state-adopted materials even as the state reduces the number of choices school districts have as possible instructional resources. The new accountability system seems designed to deskill teacher educators in much the same way that, nearly two decades ago, Apple and Teitelbaum (1986) warned that top-down standardization was deskilling teachers. The ivory tower has been breached: as Nelson (2003, p. 3) writes in an introduction to an issue of Teacher Education Quarterly devoted to this topic, "The teacher education profession is under siege."

Resistance, say critical teacher educators, should be our response to this onslaught. Lea (2003) writes, "Many of us who are teacher educators committed to critical multicultural education believe we have no choice but to resist the State TPEs." We can resist by working within the system through "well-informed collaborative action" (Ahlquist, 2003, p. 63), and outside the system by, for example, refusing to administer the required test to our students (Gibson, 2003). "What would happen," Ahlquist (2003, p. 63) asks rhetorically, "if teacher educators . . . didn't comply, but wrote programs which supported major concerns of a quality program that they have researched and tested over time? What if CTC didn't certify these programs? Would the sky fall?" The sky wouldn't fall, but, in all likelihood, we would lose our accreditation, our students, and, ultimately, our jobs. Such a development certainly would not help our students or the public schools in need of credentialed teachers.

As teacher educators, we are in a difficult position. In spite of our desire to resist the new standards, we are under enormous pressure, both from within and outside our universities, to comply with them. A more pragmatic alternative to open rebellion could be to remain critical of topdown bureaucratic control while continuing to work with preservice teachers-acquainting students with our critical perspective at the same time as providing them with the knowledge and skills required to pass the TPAs. Using as a guide Goodman's (1988) taxonomy of political tactics in a conservative teaching environment (overt compliance, critical compliance, accommodative resistance, resistant alteration, and transformative action), it seems more effective to practice critical compliance or accommodative resistance than to risk being shut down for transformative action.

Subversion, rather than open rebellion, is certainly not a new strategy for educators. Lipsky (1980) writes that in "street-level bureaucracies"schools, police departments, legal services, and other large organizations in which the "street-level" workers interact with and dispense benefits or 
sanctions to their "clients"-policy at street-level does not reflect the exact plans of top-level management, but instead is established during the frequent encounters between street-level workers and their clients. Many critical teacher educators exhibit the qualities of Lipsky's streetlevel bureaucrats, who, Lipsky (1980, p. xiii) writes,

... believe themselves to be doing the best they can under adverse circumstances, and [who] develop techniques to salvage service and decision-making values within the limits imposed upon them by the structure of the work. They develop conceptions of their work and of their clients that narrow the gap between their personal and work limitations and the service ideal.

For critical teacher educators, the "service ideal" involves maintaining that critical stance and infusing it into our work developing, administering, and implementing our credential courses and programs-and making sure that we communicate our critical stance to our students-at the same time as preparing our students to become successful teachers. Meanwhile, the critical teacher educator can continue through scholarly discourse and work with colleagues to agitate for changing the system.

But is it really possible to develop and carry out a program that can pass muster with the CCTC, while retaining a critical stance? How, as Greene (1995, p. 11) asks, are we "to avoid feeling like a chess piece or a cog or even an accomplice of some kind?" Berlak (2003, p. 39) reminds us how insidious corporate-directed change can be:

In the early part of the century skilled craftsmen who had formerly combined conception and execution, thought and action, in the building of automobiles became cogs in Ford's assembly line, as alternative forms of production were destroyed. They became the executors of movements prescribed by others. This is what classroom teachers and teacher educators in California and other states have increasingly been experiencing during the past decade. It took only a generation or two for assembly line workers to accept being cogs in a wheel, unable to imagine it could be any other way. What will happen when those who are teaching can no longer recall a time when teachers and teacher educators were encouraged to construct a curriculum that is appropriate for their students and for the historical moment in which they find themselves?

Berkak's concerns involve more than just the way teacher educators 
feel about their work with teacher candidates; she is also writing about how we conceive of what we do. If we forget our history as teacher educators, then we forget what we once believed about teacher education; we replace our old ideals with an ideology driven by a discourse of standardization and serving institutional interests.

As our department developed and implemented its new standards-driven secondary credential program and prepared for an upcoming CCTC review, we asked ourselves the question, "Are we serving as cogs in the CCTC's wheel? That is, by participating in the system we deplorepreparing our students for the high-stakes test they need to pass-aren't we helping to support and perpetuate that system? Is working within the system blunting the edge of our critical perspective, deskilling us like Ford's workers, or are we able to maintain our ideals and beliefs in spite of the mandated changes we have made in our program?" Our critical perspective notwithstanding, to what extent are we, imperceptibly but inexorably, being drawn into Secretary Paige's river flowing west? We embarked on a self-study to explore these questions.

\section{THE SELF-STUDY PROCESS}

This self-study grew out of conversations that we (the authors) were having among ourselves and in department meetings as we began revising our credential program-aligning our courses to the new standards, writing the required document, attending CCTC workshops and meetings, and, after the document was approved, implementing our new program. Time and again, faculty conversation would return to the question that eventually became the basis for the research study: Can we create a program that upholds our ideals of a progressive, caring, learner-centered environment that still meets the state requirements? We noted the specificity of the new standards and wondered about the relationships between the changes that had occurred in the discourse of teacher credentialing and the changes that might occur locally in our work as teacher educators. Thus, we began planning this study in the manner Pritchard describes in his discussion of practitioner research: "Practitioner researchers understand research as an integral part of what they do in the ordinary course of events as a way of improving their regular practice" (2002, p. 4). Our "multi-instrument approach" (Pelto, cited in Wolcott, 1988, p. 192) to data collection made it possible to examine the data from a variety of perspectives. Data sources included interviews with faculty members, CCTC documents, course syllabi, and other written material such as the minutes of department meetings and the minutes of the research team's discussions. Key to our data were the 
ongoing conversations, impromptu as well as planned, among faculty in the department.

We conducted interviews with all nine full-time faculty members in the department, plus the "Educator-in-Residence" at the time of the program revision. ${ }^{1}$ Included in this process were interviews that we conducted with each other. We designed a semi-structured interview protocol that focused on how each participant in the process perceived his or her role, the work each was asked to do, and its effect on each individual's teaching, scholarship, and the credential program in general. Each interview lasted approximately one hour, and notes from each of the interviews were written up and read by interviewees as an initial member check.

As we began to analyze the word-processed interview data, we noted that some faculty members had pointed out differences between the CCTC approval process and the NCATE review preparation in which we were involved at the time that we were conducting this self-study. A number of respondents also compared our state-mandated SB 2042 program revision to the previous revision, in 1999, which the department had initiated and carried out in order to secure CCTC authorization for CLAD (Cross-Cultural Language and Academic Development) designation for our credential program. During this earlier program development, faculty had reconceptualized the entire program, course content, and evaluation procedures in order to create a stronger focus on multicultural, anti-bias education and on the equitable education of linguistically and culturally diverse adolescents. Given the remarks about the differences between the two CCTC approval processes, we collected records and documents that members of our department had created in accordance with the pre-SB 2042 (CLAD) credential program in order to compare them with analogous documents created for new SB 2042-mandated program. These included the CCTC-approved program documents, seven course syllabi, minutes from 34 department meetings, student portfolio requirements, and other forms of evaluation from the 2000-2001 and 2002-2003 calendar years. And we added a question to the interview protocol that asked participants to discuss how they would compare the two processes. Thus both data collection and data analysis were recursive and involved progressive focusing as we continually clarified, refined, and adjusted our working findings.

Data analysis was a multilayered process. We began by conducting open coding of interview notes and program documents. Research team members first worked independently to discern the emerging categories he or she saw in the data, and then sought both confirming and disconfirming evidence in later interviews and document analysis. Throughout the course of data collection, we met regularly as a team to discuss and revise 
the categories and to re-examine data in light of new revelations that came out of our discussions.

As we read and discussed the notes and documents, we returned to the work of Gee $(1996,1999)$ and Luke $(1996,1997)$ to provide a theoretical and analytical frame for the self-study. According to Gee, the way we use language not only represents perspectives, but creates them as well. That is, language in use is both constituted by and constitutive of the context in which it occurs. In our case, the context of the language we were using and analyzing was the current climate of state-mandated standards-based teacher education. Language and other symbolic systems in use are part of what Gee discusses as ways of being in the world. People negotiate roles and identities within and across the discursive practices in which they participate. Luke (1996, p. 13) also discusses how texts construct particular social worlds making certain subject positions available:

Human subjects use texts to make sense of their world and construct social actions and relations required in the labor of everyday life. At the same time, texts position and construct individuals, making available various meanings, ideas, and versions of the world.

But texts can also be used to contest and critique that which is taken for granted or considered common sense. As Luke (1997) explains, a critical examination of the spoken, written, and other symbolic texts produced in communities and institutional settings can make transparent how social relations, knowledge, power, and identities are constructed by these texts. As members of a community of teacher educators, we sought to examine the impact of the new teacher education discourses on our community.

Because we were responding to written mandates and coded correspondences from the CCTC and in turn producing a written document that was intended to govern our actions as teacher educators, we decided that critically examining the texts produced throughout this process offered a way of making visible the effects of SB 2042 as policy for teacher education. Therefore, we undertook a close analysis of our language in use as it occurred in CCTC meetings and documents, in our department meetings, in corridors, and in the meetings we, the researchers, held to discuss our self-study. In his approach to discourse analysis Gee (1999, p. 97) recommends looking at the data in terms of "what situated meanings these words and phrases seem to have ... given what you know about the overall context in which the data occurred." In the situation at hand, how did the texts issued by the CCTC and our response to them in meetings, 
in conversations, and in the format of promised practices in our new program document construct us as educators and students as candidates? What counted as knowledge in teacher education and whose interests were being represented? This analysis enabled us to examine the kind of readers and writers, speakers and teacher educators we became during and after the process of writing and implementing the SB 2042-mandated credential program.

\section{IMPACT OF THE NEW PROGRAM}

Our study revealed that our participation in the new, state-mandated program has influenced us and continues to influence us in a variety of ways. There have been three distinct phases of this process: program approval, implementation, and ongoing involvement. During the program approval phase, ${ }^{2}$ which took place during Spring semester 2002, members of the department wrote up the mammoth document according to the CCTC Standards of Quality and Effectiveness for Professional Teacher Preparation Programs (2001) mandated by SB 2042; the implementation phase took place in Spring semester '03 when we first introduced the new, approved program to our students; and ongoing involvement refers to the time following our implementation semester during which department faculty and our students settled into and became accustomed to the new program.

\section{The program approval process}

The program approval phase took a tremendous toll on faculty members involved in writing and preparing the program document. Interviews revealed strong reactions of anger, resentment, and fear, as well as feelings of helplessness and inadequacy. "I was angry that we had to do it," says Perry, ${ }^{3}$ who attended "Technical Support" meetings (workshops detailing how to write and prepare the document) in Sacramento and shared what he learned with the document writers. "I didn't see any value in doing it, and it didn't help us to rethink or reshape our program. But, as Department Chair, I had to swallow hard because there is a program here to protect. I was torn by my responsibilities [to support the process and those writing the document] . . . and my personal feelings." Others were more dramatic but no less upset about the mandate: John recalls "the profound silence in the room as we were read the rules [specific requirements for all programs] at that first [School of Education] meeting. ... I had strong feelings of a collective sense of defeat, outrage, and helplessness. I never before had felt so helpless ... in my professional life. 
I felt as though there was an anonymous power controlling our destiny. No one could protect us from it; we were naked in the dark."

The two faculty asked to write the document itself were certainly the most burdened throughout the program approval stage. Karen and John had to familiarize themselves with the standards; gather information from department faculty about the courses they teach and evaluation procedures they conduct which would serve as the required "lines of evidence" to support the department's assertions that our program was meeting each and every element of every standard; and, of course, write the document itself, addressing, in order, each element of each standard. "I worked every weekend," Karen says. "I was overwhelmed and confused. I couldn't understand why they wanted the kind of [bureaucratic] language we had to use. It was a new genre." Says John, "Writing the document was a demoralizing process. It was like getting whacked on the head. . . . Every section was only slightly different from the one before. . . This process made me write badly." Writing the document was a process of such intense standardization that John and Karen were told, "Always remember when preparing this document that redundancy is your friend."

The senior member of the document preparation team adopted a more historical perspective of the process. "My role was as sort of the experienced elder," explains Marty. I wrote our previous document and the one before that, and the one before that too, since 1985." But for Marty, this process felt different than the previous program development processes: "It felt like the tightening of a noose. First of all, the amount of legislative mandate was unprecedented. Never before had we been told specifically what we had to do and how we had to do it. The incredibly detailed requirements. The signal to us was 'we don't trust you to do what we want, so we'll tell you what to do.' . . . It was so disheartening, so demeaning, to have to respond to legislative and CCTC regulations and standards which so clearly question our professionalism. I was angry."

In addition to emphasizing the difference between this process and previous ones, Marty also noted differences between CCTC program approval and the NCATE accreditation process. "How I felt [preparing the CCTC document] was distinctly different from how I felt when we as a faculty decided to seek NCATE accreditation," she says. "At the NCATE meetings, nobody tells me what to do. They say, 'What do you want to do?' and 'Now show us how you do it." Marty's NCATE meetings differed markedly from Perry's experiences at SB 2042 articulation meetings at CCTC in which, Perry reported, he was given the standards and told exactly what the department needed to do to meet those standards. When he raised concerns about certain standards or the feasibility of 
implementing the TPAs, he was told that there was no room for discussion, that our department had better get with the program or else suffer the consequences of being out of compliance. As he explains, "Prescription and oppression are synonymous. . .NCATE-that's our choice-that's different."

As the "experienced elder," Marty sought to mitigate the negative impact on the newer faculty, particularly the two writing the document, who had never participated in a CCTC-mandated program approval process. "I saw [my role] as a way to lead those doing it for the first time," offering suggestions, taking drafts of their documents and putting them into formats that would appeal to the CCTC. "I felt it a responsibility," Marty says. "Part of my role was to be a buffer for [them]."

While Marty had many times provided support and guidance when working with less experienced faculty members, the process of assisting with the new standards document began to undermine that particular social role and identity. As Marty noted, she could only "watch helplessly" as the newer faculty struggled to gather the needed information and write the document, all the while becoming increasingly disillusioned and demoralized. Karen, who was new to the university that year, had actually volunteered to write the document. "I thought it would be an experience like curriculum development, ... that it would be a visionary experience" in which we would "make the curriculum better." She soon felt, though, that she had made a serious mistake. Her original expectations of the process, she says, "made it all the more onerous and depressing. It took so long for me to understand the required redundancy [in the writing]. Who would want to read this?"

Insecurity and worry soon replaced disappointment. Anyone who has negotiated with the CCTC knows that obtaining program approval is almost never a quick or straightforward process. CCTC readers go over each standard word by word and return the document with detailed recommendations for revisions, which must be addressed in the next draft. As the primary author of the section on Standard 13, Karen felt the disciplinary effects of their review as she read a fax the CCTC document readers sent to the Dean. The standard had not been met, they wrote, because the response was deemed "not clear." CCTC's power to dictate the minutia of syllabus design and class procedure, however, was very clear in comments such as, "Key concepts and theories . . . are given in the response to the standard, but the syllabi do not show the panel where and when this actually takes place within the course" [emphasis in original]. For Karen, the CCTC's rejection of parts of the document and their demand for ever more specificity were mortifying: "I was completely upset and appalled at myself and embarrassed and humiliated by the 
rewrites [that CCTC required]."

Karen's feelings of humiliation were the culmination of a process in which she had participated throughout the semester. At the CCTC's Technical Assistance Meetings, which, as one of the document writers, she was required to attend, she sat through workshops and was given documents which detailed precisely how the credential program needed to be structured and how the document needed to be written in order to earn CCTC approval. Along with a roomful of PhDs from institutions of higher learning throughout the state, Karen received a hot-pink sheet of paper with the day's agenda:

“Today's Outcomes. Program Sponsors will understand:

recent policy directions. . .

guidelines and expectations. . .

how to write and submit program documents. .

how to access additional technical assistance."

This discursive claim to power over faculty document writers marked CCTC as the regulator of information. Any contestation by faculty would then be at odds with the designated outcomes. CCTC assumed the power to direct the actions and discourse of the participants and to control what constitutes important knowledge for teacher educators. The list itself further reflects the subjugation of teacher educators: there was no desired outcome related to writers' ideas or concerns, no opportunity for autonomous action, only technical outcomes deemed necessary by the CCTC.

During the morning session, Karen and the others were told by their "trainers" to underline key words and phrases in the standards document (such as "develop pedagogical competence as defined in the Teaching Performance Assessment"), and were given handouts ( "SB 2042 Draft Standards-Board of Institutional Reviewers Training Program Content Analysis of Standards-Lines of Evidence," 2001) providing the "explications of key words or phrases" such as "Embedded in the curriculum of the program is direct instruction and directed practice in the pedagogical competence as defined in the Teaching Performance Expectations." This language, which typifies the directives contained in all CCTC documents-from short lists of program do's and don'ts to the comprehensive Standards of Quality and Effectiveness for Professional Teacher Preparation 
Programs (2001) - positioned Karen and the rest of the document preparation teams as unskilled workers, people with so little expertise and knowledge about teacher education that they needed explicit directions about how to develop an acceptable program. One of the professors from another institution asked Karen, "How do you stay engaged with this kind of writing?" Karen replied, "The only way to complete the writing is to try to be disengaged." Karen's disengagement epitomizes exactly the surrender of agency that Paige's river metaphor promotes.

To fully understand the meanings of the new CCTC regulations, we must read the language of CCTC memos and documents related to SB 2042 against the regulatory language of previous program adoption cycles (from which they differed significantly), manifesting, as Marty suggested, an unprecedented level of prescriptiveness. So, whereas our CLAD certification was predicated on our addressing "factors to consider," SB 2042 required that we provide "lines of evidence"; syllabi in the CLAD program needed to demonstrate congruence between our course goals and CLAD domains; now, for SB 2042 approval, "Individual course syllabi and/or course readings and assignments [must] show direct instruction in state-adopted K-12 academic content standards and state adopted instructional materials" (CCTC, 2001, p. 2).

The new language represented a notable shift in power from local education faculty to the state licensing board regarding curriculum decisionmaking. The term "factors to consider" had provided a framework that assumed teacher educators were themselves knowledgeable professionals who could be trusted to prepare new teachers; the change to "lines of evidence"-whose worthiness, Karen learned, was adjudicated by the CCTC-epitomizes the state's ideological shift (described above) from teacher educator as skilled craftsman to teacher educator as $\operatorname{cog}$ in the wheel (Berlak, 2003).

With CCTC providing such explicit instruction, it's little wonder that Allison, who had been a faculty member for more than ten years, "worried about whether or not I was doing it properly." Whereas in the past, she might have trusted her experience in the field and her curricular conversations with colleagues, now she depended on CCTC to let her know how she was doing-because she knew the state, in the end, would determine what was worthwhile. "Why," she asked, "isn't it enough to have the knowledge, education, and experience to design courses?"

Karen's humiliation exemplifies the way the faculty were positioned by the CCTC and the approval process we had to undergo to meet the SB 2042 mandate. When we asked faculty members to think of a metaphor for the process, we received such responses as assembly line worker, Dilbert (the comic strip), a Nazi labor camp, a ship with a rudder that 
cannot be adjusted, children with stern, unyielding parents, and so on. In this age of accountability, this type of reaction to an accrediting body's oversight is not uncommon. Jeffrey and Woods (1996), for example, found that faculty response to the "technicist approach" of Great Britain's Office for Standards in Education (OFSTED) was anomie, anxiety, and doubt about their competence, resulting in what Jeffrey and Woods call "deprofessionalisation." For the majority of faculty members, the CCTC's restrictive language and requirements successfully positioned us in exactly the same way, as powerless, degraded wards of the state. As Marty explains, "The whole purpose of the process was to make us powerless: the powerful exacting punishment, the powerful ones bringing down judgment."

The language with which CCTC (and OFSTED, and many other accrediting institutions) position faculty as powerless participants in this approval process reveals a shift from the ideal role of accrediting institutions like the CCTC. Theoretically, the CCTC and schools of education work together to ensure that teacher education candidates receive preparation that all parties consider worthwhile. The accrediting body, in consultation with the schools of education, develops frameworks within which the universities (and P-12 schools as well) agree to operate. As recognized experts in the field, university faculty develop programs congruent with research and their beliefs about education, at the same time maintaining the principles upon which all parties have agreed. And, periodically, the accrediting body visits the schools of education to help them remain true to their agreements. The relationship between these parties is a covenantal one: the accrediting body agrees to respect and support the schools of education, while the schools of education agree to uphold the standards that they developed collaboratively. While our university's relationship with CCTC has probably never been quite as collegial as this sounds, faculty remember the CLAD adoption process as being much closer to this ideal than the SB 2042 approval process; and, as Marty points out, the NCATE approval process, while time-consuming and difficult, is predicated on this type of covenantal relationship with the accrediting body.

The CCTC's language of control throughout the SB 2042 approval process demonstrates that its relationship with schools of education is no longer a covenantal one. It has evolved into a coercive one, in which schools of education have no choice but to metaphorically sign the contract written by the CGTC, and then adhere to its conditions. A concerned faculty member told colleagues, "We promised to integrate this [curriculum] into our new program; we need to look at the promises we made"-but in our current relationship with CCTC, promises are not 
necessarily the result of mutual agreement. Like Lipsky's street-level bureaucrats, most faculty are torn between their obligation to the decision-makers to uphold all their promises and their concerns for providing a program they believe in. As Perry explains, "I want to make sure that this program, with the consent of the faculty, is of the highest quality; but I also have to ensure the quality of the program from the point of view of the CCTC. Failure to meet the standards puts us out of business." Perry's statement captures the tension that our required adherence to the new standards created for some of us. Our vested interest in maintaining access to social goods and material resources bestowed by policymakers made us complicit in regulating our own actions and beliefs.

CCTC language notwithstanding, faculty less directly involved in producing the document voiced considerably less concern over CCTC's more prescriptive role in the development of the new program. "I feel that having standards is a good thing," says Antonio. "In general, I value the process-but only if it's done with forethought by the accrediting agency." Nancy, the Educator-in-Residence, also found value in the standards: "It made me aware of what CCTC considered essential skills. It was helpful to [me] to have clarity about what the target skills are. . . I kind of liked the TPEs. I thought they made sense." Victoria disapproved of the prescriptiveness of the new standards, but in general approved of their focus on content and school/university communication. "I'm a rational person," she explains. "This was a new set of standards. We're in a field of standards. It's nothing new." Peter called the CCTC's top-down directives "anti-intellectual," but said that "the tasks were OK. We did what was necessary. The process was OK." Although Allison worried about "getting it right" when she provided Karen and John with information to include in the document, overall, she seemed to take the new standards in stride, characterizing CCTC's mandate as more of a nuisance than evidence of CCTC oppression. "Sometimes it's hard to take it seriously," she says. "We change the words, we change the labels. Does this help at all? Does it influence at all what we take into teaching?" Here Allison contests the positioning of being either right or wrong as determined by an outsider not in her classroom and not part of our program. Instead she opts for a third position, distancing herself from CCTC's judgment.

Considering their indirect involvement with the approval process, it is not surprising that these faculty report that little in their lives as scholars and teachers changed as a result of the process. Unlike the document writers and preparers, they were not directly confronted with the CCTC's discursive practices. Karen, John, and Marty, who were responsible for gathering information (course syllabi, assignments, etc.) from the other 
members of their department, did not demand lines of evidence; they politely asked for course materials and told their colleagues that they'd use the information to give CCTC what it wanted. Attempting to reshape the authoritative and narrow discourse of teacher education coming out of Sacramento, they positioned themselves not as enforcers or agents of the CCTC, but as intermediaries between the CCTC and fellow faculty. Occasionally Karen or John went back to faculty with suggestions regarding more specific information they needed, but the dynamic was considerably different from CCTC's admonitions to Karen.

Those immersed in the approval process point to much more marked changes in their outlooks than the rest of their colleagues. In most of their frequent meetings in Spring 2002 to discuss writing the document, Karen and John's conversation would move to their concerns and frustrations about SB 2042. "John and I discussed ... this process as part of the bigger picture-accountability as oppression," says Karen. John concurs: "The process has radicalized me. . . I see [SB 2042] as part of a process that is much larger. It has given more meaning to my work. It's part of the New World Order: globalization, standards, top-down bureaucratic control." In fact, it was at one of their SB 2042 document writing meetings that they began to consider the impact of the language of top-down program development on their thinking. Says John, "My talks with [fellow faculty] about these issues helped me to clarify my thinking and get me moving [on scholarly examination of these issues]."

Perry has transformed his anger into activism in his writing, presenting and publishing several papers on the oppressive nature of the Teaching Performance Expectations. "My time should be better spent theorizing about social studies," he laments, but "there have to be critical voices against the high stakes standards movement."

Marty, the veteran faculty member who oversaw the process and supported Karen and John throughout, has responded differently. As she explains, "Focusing on NCATE is my form of resistance to the SB 2042 standards." Instead of listing the TPEs on her syllabi, she lists the NCATE Performance Expectations and Dispositions which our School of Education collaboratively developed. Still, the process has taken its toll on Marty. "It solidified my desire to retire. I'm tired of being treated like an errant child. I'm tired of being told that my years of experience, scholarship, and knowledge have no value. ... I'm thrilled that I'll never have to write another document for CTC. I'm looking forward to leaving a toxic environment."

Thus, not only were those most involved in the program approval process the most troubled and angry throughout the process, they were 
also the most radicalized as a result of their participation. The CCTC's language of control inspired its street-level bureaucrats, positioned as powerless pawns obediently carrying out their policies, to scrutinize that language and resist those policies: as with Freire's (1990, p. 61) students, the CCTC's coercion inspired "formerly passive [faculty] to turn against their domestication and the attempt to domesticate reality."

\section{Implementing the new program}

While response to the program approval process varied among the faculty, almost everyone recalls a difficult and painful first semester implementing the program. Soon after CCTC approved the new program in Fall 2002, the department announced to students that it would implement this program in the upcoming semester, Spring 2003. The changes were more procedural than substantive, but many students, who had carefully planned their lives around the old requirements, were furious at these changes, pointing out that they could afford neither the time nor the extra money that the changes would require. And the procedural changes themselves continued to evolve as policy-makers at CCTC thought through more details regarding implementation of SB 2042. As Nancy recalls, "Yesterday's right answer was today's wrong answer. It made [us] look like idiots."

Our students' response to our directives was disturbingly similar to our response to the CCTC. Now we were the entity that was quoting specific standards and citing the TPEs to explain the new requirements: although we had not originated this discourse, in our students' eyes we were the entity mandating changes in a dictatorial, technocratic manner. Of course, we had little choice in the matter: we had to implement the changes, including those we didn't believe would improve teaching and learning in all content areas. One example of just such a change is found in Standard 7B(c) (ii) (discussed above), which calls for candidates in all content areas to have instruction and experience in "teaching organized, systematic, explicit skills that promote fluent reading, including decoding skills and spelling patterns" (p. 11). Both the CCTC and (as a result of the CCTC's control over our programs) our students were positioning us as Dilbert-like bureaucrats implementing policy and procedures that were not of our making.

Our responses to students' anger varied. Karen, Perry and Marty used the sudden (and, in the students' eyes, capricious) change as an opportunity to illuminate the CCTC's power over the university's credentialing programs, that we were essentially helpless to mitigate the impact of this change on students' lives and pocketbooks. John and Allison, on the 
other hand, left the CCTC out of the explanation and put a positive spin on the changes, focusing on ways that some revisions could actually enhance students' preparation and make them better teachers. Both responses indicated a desire to distance ourselves from the CCTC, to assure students (and ourselves) that the accrediting agency's intrusions had not negatively affected our teacher education program.

Nevertheless, either response was troubling for faculty members. Blaming the CCTC diminished our authority in the eyes of our students. Says John, "I was afraid that, if they saw us as powerless to resist the CCTC in this matter ... they'd think everything we do and teach is what the CCTC tells us." But his solution-to "spin my responses to questions" in order to make the program look less controlled by CCTC (and to downplay his role as a bureaucrat in an attempt to maintain his identity and image as a professional)—was disingenuous to his students. Successful teaching involves building and maintaining caring, and, above all, honest relationships among teachers and students. As Ayers (1993, p. 127) notes, teaching "requires a thoughtful, caring person at its center."

Thus, in spite of our attempts to separate ourselves from the CCTC, our responses to student anger at the changes aligned us more closely than ever to the CCTC: we had shifted identities from teacher as thoughtful caring professional to teacher as technician. Although much of the content of our credential program varied little from the previous program, the relational dimension of our work with students had changed: the CCTC's shift in its association with schools of education had led us to commit a similar violation of the covenant between our students and us. As Allison points out, we had fallen into the service role that increasingly pervades university culture, treating our students as customers we must be sure to keep satisfied: "We had to keep justifying what we were doing without believing in all of it."

\section{Ongoing involvement with the new program}

While all faculty acknowledge the difficulties and dilemmas of that implementation semester, they also agree that the situation improved soon after. Student complaints disappeared as the first cohort moved through the program and prospective applicants learned, well before applying to the program, of the new requirements. With students accepting the regulations of the new program, we no longer had to assume the position of disempowered bureaucrat. Now that the program has been in effect for a few years, many faculty regard that first semester as something of an anomaly-that, aside from the temporary pains in the program's inaugural semester, the whole process of writing the new document, seeking 
CCTC approval, and implementing the new program, has had little impact on what we teach or what students learn in our credential program.

In fact, those directly involved in preparing the document for CCTC made a conscious effort not to let that process, and the resulting program, affect their teaching or the program that had been in place prior to adopting the new one. John explains, "I did nothing to change my classes except to make sure students are aware of the standards driving our program." According to Perry, "It didn't improve what we do. If anything, it has taken resources, time, and energy away from what we could have done. I had hoped that maybe something [would have resulted from the process], but I can't think of one thing that has made our program better as a result of 2042." And Marty argues that any changes she made in her teaching were the result not of SB 2042 but of the kind of collaboration and reflection that she engaged in throughout her career. In the summer, she and Karen would meet to discuss the content of the course they both taught, and, together they decided how they would change it. Once, for example, they decided to modify an assignment that Marty had been using for the past 30 years. "But that change," Marty says, "did not come from 2042; it came from my professional exchange with my peer. That's how to create meaningful change. We have affected the quality of the program."

According to these faculty, if SB 2042 has had any impact on their teaching, it has been to inspire them to help their students to consider the shortcomings of SB 2042 and the system for implementing it. Perry had always required students to critically examine state frameworks in his subject area; now, he has students also critique these state standards. "When we talk about state standards, about the TPEs, about content standards, I use the metaphor of the low bar, which we can easily jump over; but we can look higher and more broadly." Similarly, Marty emphasizes the superiority of the NCATE Performance Expectations and Dispositions, developed by our own faculty, compared to the non-negotiable TPEs. And John states that there is more of "an edge" to his teaching: "I make a point of helping students to see ... what's going on. I make the politics of education a focus of my teaching." Similarly in her classes, Karen often discusses SB 2042 as just one example of the standardization of education and what that means for teachers and students.

Among the rest of the department faculty, no one says that the TPEs have significantly affected his/her teaching; but several acknowledge minor improvements that have resulted. "I don't think it's changed my teaching," says Antonio, but "writing to the new standards enabled me to do some activities that the accrediting body would recognize as meeting 
the standards." Allison says that the process "did clean things up a bitlike spring cleaning. ... I look at my syllabus more with a fine tooth comb, streamlining and focusing the way I look at a course." And George acknowledges that, although he's made no significant changes in the program course he teaches, standards issues are more prominent in his course readings, discussions, and activities. But like Perry, he uses this added focus to encourage analysis, not blind acceptance. Having been on sabbatical during the semester that the department was seeking CCTC approval, George offers a more detached appraisal than anyone else of the new program's impact on the faculty, and puts the slight shift in his course focus-as well as the varied responses of all department facultyin a positive light. As a result of the process, he says, "faculty have become more astute, and more aware of the issues involved in standardization."

All in all, the general perception among faculty of the ongoing impact of SB 2042 has been that our teaching and programs have been, for the most part, unaffected by the new program, and that our increased awareness of the impact of standardization has been beneficial to us and to our students. Yet statements by each faculty member about the courses they teach cast some doubt on those assertions:

Allison: "The TPEs have been integrated smoothly into class discussions, and through assignments [related to] classroom observations."

Karen: "In the first semester of the new program I didn't talk much about the TPEs. Now I reference them more often."

Perry: "The conversation of how does your content relate to the content standards [referenced in the TPEs] is a conversation I didn't have [with my students] five years ago."

Karen: "We are compelled to do more with technology."

Marty: "We're doing a mini-TPA 3 activity [in one of my classes]. ... In [another class], the TPEs are in there. We'll talk about which classes address which TPEs. After the students get comfortable with the TPEs, I'll use a handout to show them the connection between the TPEs and [NCATE] Performance Expectations and Dispositions."

Peter: "We have a responsibility to teach the standards; students have a right to know this information." 
Nancy: "We have students highlight their observation logs in relationship to the TPEs."

Antonio: "I've been asked to step up with technology standards."

Could it be that, contrary to our perceptions, our teaching is changing? With this question in mind, we might reconsider some of the statements that faculty made to assert the lack of change in their approach to their courses, such as:

George: "I've made no significant changes in [the course I teach], but the standards issues are more prominent, and more explicit in the readings, discussions, and activities." (emphasis added)

John: "I did nothing to change my classes except to make sure students are aware of the standards driving our program." (emphasis added)

An examination of our syllabi and program materials reveal a similar heightened emphasis on standards and the TPEs. The former program had used the California Standards for the Teaching Profession (CSTP) the old standards upon which the TPEs are based-as the basis for assessing student progress in the program. But few of the old syllabi mentioned standards, and the program handbook referenced them only infrequently. In contrast, most current syllabi contain repeated references to the TPEs-often in bold type-and the handbook lists them prominently. Nancy notes that TPEs serve a useful function because they "give everyone a common language for talking." But in light of Gee's (1996) notion that Discourses (he uses the term Discourses with a capital D because they involve more than just language) create and constrain ways of being in the world, this "common language" achieves more than just providing us with a shared vocabulary; it serves to standardize our courses, our programs, and our ideas about teacher education. It is, in effect, a normalizing discourse, which has the potential to render invisible other kinds of knowledge and pedagogies (e.g., teaching candidates about using texts that are not state-adopted, teaching candidates about adolescent literacies from a sociocultural perspective, etc.). As Karen admits, adopting this common language "has narrowed some of the ways I think about what we do."

Faculty members' adoption of this "common language" is apparent in the evolving discourse in the department. Notes and transcripts of meetings reveal that our language has become considerably more techno- 
cratic over the past few years. Phrases like "We need to do this so that students can meet the technology standards" or "With the new standards, we need to make sure that ..." would have been met with derision in previous years; now, they are met with nods and entered into the minutes. (Perry argues, though, that his use of bureaucratic language like "aligning curriculum to the standards" is satirizing the language of the enemy and not meant to be taken seriously.) In fact, whereas the word "standards" does not appear in any monthly department meeting minutes from the 2000-2001 school year, words like "lines of evidence," "TPEs," and "standards" appear in the minutes of almost every spring 2002 meeting-not surprising considering that we were writing the program document during that semester. But these words also appear in minutes from almost every 2003 meeting-even after the program had been approved, the difficult implementation semester had ended, and we felt that our teaching, our relationships with our students, and our ongoing involvement in the program had returned to normal.

Clearly, in spite of our assertions that little has changed in our program, our language- the way we describe what we do and what we expect of our students-is changing. In light of the CCTC-mandated process in which the department participated throughout the program approval process, this change is not surprising. The text that we produced during that semester was imbued in our documents and our conversations; it became part of who we are. And we continue to produce this text in our conversations with one another and our lectures, discussions, and activities with students. We may have struggled with it and fought against it at first, but now we accept the language without question. As Perry points out, "If you keep saying, at every meeting, that the standards are fascist, people just start rolling their eyes. They don't say you're fighting for freedom; they say you're being obstructionist." Former secretary Rod Paige's accusation that those who oppose No Child Left Behind are "terrorists" (which he later revised to "obstructionists") demonstrates that positioning dissenters as anti-reform and worse (anti-American? anti-democracy?) is taking place at all governmental levels.

This shift in language is not merely a superficial evolution of buzzwords, from "factors to consider" to "lines of evidence," from CSTP to TPEs; it reflects a more substantive shift in the ways we think about what we do. Now, rather than considering curriculum on the basis of what we believe is best, we think of changes in terms of what CCTC will allow us to do. So Peter said to a colleague, "This is what I want to do in my class next semester; but, oh, I've got to figure if that fits into some of the TPEs." And we are grateful when the TPEs allow us to do what we want. Thus, Antonio is pleased that "the new standards enabled me to do some 
activities that the accrediting body would recognize as meeting the standards" (emphasis added) - but he's not bothered by the idea that, as a result of the accreditation process, he has been positioned as being permitted to conduct the activities that his knowledge and expertise suggest. Our language seems to indicate that the new standards and TPEs have become imprinted in our consciousness, like the messages imprinted, body and soul, in the criminals of Kafka's (1995) penal colony.

Of course, we would like to think that what we say can be different from what we do. That is, even though we talk about TPEs with students, we aren't changing the substance of what we are teaching. That's why Antonio says that the new program has "changed my communication with students," but "I don't think it's changed my teaching"; and Perry says "it has changed some of the conversations, not my methodology per se." But what we say does affect what we do; in fact, Cherryholmes (1988, p. 7) argues, "All speech is action. . . . What is done with an utterance is material" (emphasis in original). We're engaged in a struggle, and that struggle can be seen in our attempt to maintain a discursive space for the philosophical perspectives that brought us to this profession. Perry epitomizes this struggle when he admits, "Over the years my philosophy has not changed, but, in my role as Department Chair, I think I have to look at the fact that I'm responsible for the quality of the program. . I don't want to get dinged by CCTC for being inconsistent and not meeting the standards."

So, because we have little choice, we agree to change the way we talk in order to satisfy CCTC-but at the same time we endeavor to remain true our ideals. But Cherryholmes (1988, p. 7) notes that, "When one says something one is doing something, and its meaning is relative to setting, context, rules, and so forth." So words uttered in one context may have a different meaning than the same words spoken in another. If, for example, we were teaching in an environment whose discourse valued inquiry, choice, and diversity of perspectives, then our encouraging students to adopt these beliefs and practices might carry more weight; instead, the "toxic" environment that Marty describes pollutes all that we say and do. How can we convince students they must work to counteract oppressive structures in their schools and districts if they see that we are powerless to effect systemic change in our own environment? Caught in the swiftly moving current of state-mandated compliance, we are struggling to stay true to our ideals as we grapple with the question Foucault (cited in Cherryholmes, 1988, p. 36) asked years ago: "How can people gain control of their discourses and practices instead of being controlled by them?" 


\section{CONCLUSION: SWIMMING AGAINST THE CURRENT THROUGH CRITICAL CONVERSATION}

A growing number of states are adding increasingly stringent requirements to teacher education programs, whittling away the autonomy and sense of efficacy of teacher educators. Many scholars voice concern and indignation about top-down bureaucratic control of credential programs, yet too few are asking fundamental questions about how such control is altering the perceptions of even those who deplore these developments.

A few years ago, our school of education conducted a self-study of our programs (Kornfeld, Marker, Ruddell, Cooke, \& Fernlund, 2003) examining how well we prepared our students for the realities of teaching. Our observations and interviews of our graduates suggested that we had not adequately prepared them for the politics of teaching. From that study, we realized that we needed to find ways to prepare new teachers to thrive in the system, yet at the same time to instill a commitment to work toward systemic change.

In light of our latest self-study, this goal at first glance seems even more elusive. The problem has revealed itself to be more complex than we had previously realized: it is not just our students, but also teacher educators like us who must ask how to thrive in the current system of teacher education while maintaining our critical perspectives in word and deed.

A year after writing the SB 2042 program document, well after the difficult implementation semester had concluded, John and Karen were developing new questions-aligned, of course, to the TPEs-which interview teams would ask candidates at their program portfolio presentations. John had emailed Karen a draft of the questions, one of which aroused her concern. She wrote,

I was wondering about the language in \#2 “ . . perceive as meaningful." Is that the wording used in the TPEs? I don't have any of the materials here at home. It sounds just a bit awkward to me, but if that is what they/we are looking for, then no big deal. I was thinking about a more constructivist lingo, such as "what strategies . . . to enable students to learn meaningfully"-yuck. How about "to engage students in meaningful learning?"

Karen's email captures the insidious influence of SB 2042 on our thinking, and, in particular, the invisible power of the language of the TPEs: if John's awkward syntax was CCTC-mandated, then, Karen was acknowledging without complaint, we'd have to live with it. But, as it turned out, 
rather than further reifying our positioning vis a vis the CCTC, Karen's email began a process that, in the end, has helped us to envision possibilities for neutralizing its impact on our thinking.

In actuality, John had not even been considering the TPEs when he wrote that question; but Karen's email helped him realize that his writing (which, as mentioned earlier, he said had become worse during the writing of the document) still reflected the syntax and style that he had adopted during the process. "Please," he wrote back to Karen, "let me know whenever I start sounding like a bureaucrat. We can't let that happen!"

This interchange marked the beginning of the conversations that would eventually inspire us to undertake this study. While we had anticipated discovering some impact of SB 2042 on our thinking and our programs, we were very surprised by the extent to which our conceptualization of teacher education had been affected by the new standards. It is easier, we realized, to say we are resisting the current of standardization than it is to actually withstand that current.

One way to resist the current, we found, is to become involved in the type of self-examination and conversation that this study required. No one should assume that he or she is immune to the effects of top-down standardization. Meeting regularly to interrogate one another's interpretations of interviews, documents, and events, and to discuss our evolving understanding of our role in the standards movement, we engaged in a process reminiscent of Freire's (1990, p. 19) conscientização, "learning to perceive social, political, and economic contradictions, and to take action against the oppressive elements of reality." The way to achieve conscientização, Freire says, is through dialogue, and it is through continued dialogue that we hope to find and resolve contradictions between what we believe and what we write and say and do. Constant vigilance, as Harry Potter's Professor Moody continually declares (Rowling, 2000), is necessary. In fact, engaging in critical discourse in this way is more than just a defensive posture; it is a political act, a way to regain control of our discourse, rather than letting the discourse control us. And our research team needs to broaden these conversations to include the whole department and school, and, eventually, others around the state and nation. As a result of this study, we plan to continue agitating for change through our scholarship and teaching while also continuing and expanding our ongoing self examination and debate into our work as teacher educators. 
1. Through our Educator-in-Residence Program, an experienced public school teacher takes a two-year leave of absence from his/her regular teaching job to join our faculty, teaching courses, supervising student teachers, and serving on department and school committees.

2. We do not refer to this process as "program development" because the program that we adopted to comply with SB 2042 was little different from the CLAD program that we had developed only three years earlier.

3. In order to allow the reader to understand our roles in this process, we, the authors, have used our real names in this study. All other names are fictitious.

\section{References}

Ahlquist, R. (2003). Challenges to academic freedom: California teacher educators mobilize to resist state-mandated control of the curriculum. Teacher Education Quarterly, 30(1), $57-64$.

Apple, M., \& Teitelbaum, K. (1986). Are teachers losing control of their skills and curriculum? Journal of Curriculum Studies, 18(2), 177-184.

Ayers, W. (1993). To teach: The journey of a teacher. New York: Teachers College Press.

Berlak, A. (2003). Who's in charge here? Teacher education and 2042. Teacher Education Quarterly, 30(1), 31-40.

California Commission on Teacher Credentialing (2001). SB 2042 draft standards-Board of institutional reviewers training program content analysis of standards - Lines of evidence (Draft document). CCTC Technical Assistance Meeting Handout. Sacramento, CA: California Commission on Teacher Credentialing.

California Commission on Teacher Credentialing (2001). Standards of quality and effectiveness for professional teacher preparation programs. Sacramento, CA: California Commission on Teacher Credentialing.

California State Board of Education (1997). Content standards: English language arts. Sacramento, CA: CDE Press.

Cherryholmes, C. H. (1988). Power and criticism: Poststructural investigations in education. New York: Teachers College Press.

Freire, P. (1990). Pedagogy of the oppressed (Trans. by M.B. Ramos). New York: Continuum.

Gee, J. P. (1996). Social linguistics and literacies: Ideology in discourses (2nd ed.). Bristol, PA: Falmer Press.

Gee, J. P. (1999). An introduction to discourse analysis: Theory and method. London: Routledge.

Gibson, R. (2003) Can communities of resistance and transformation be born from the social context of school? Teacher Education Quarterly, 30(1), 41-55.

Goodman, J. (1988). The political tactics and teaching strategies of reflective, active preservice teachers. The Elementary School Journal, 89(1), 23-41.

Greene, M. (1995). Releasing the imagination: Essays on education, the arts, and social change. San Francisco: Jossey-Bass.

Jeffrey, B., \& Woods, P. (1996). Feeling deprofessionalised: The social construction of emotions during an OFSTED inspection. Cambridge Journal of Education, 26(3), 325-343.

Kafka, F. (1995). Metamorphosis, in the penal colony, and other stories. Schocken Books. 
Kornfeld, J., Marker, P., Ruddell, M., Cooke, T., \& Fernlund, P. (2003). Through the looking-glass: Self-evaluation in an era of accountability. Teacher Education Quarterly, 30(3), $7-22$.

Lea, V. (2003). Resistance as an alternative. CCNews: Newsletter of the California Council on Teacher Education, 13(2), 4-5.

Lipsky, M. (1980). Street-level bureaucracy: Dilemmas of the individual in public services. New York: Russell Sage Foundation.

Luke, A. (1996). Text and discourse in education: An introduction to critical discourse analysis. In M. Apple (Ed.), Review of Educational Research, 21, 3-48.

Luke, A. (1997). Theory and practice in critical discourse analysis. In L. Saha (Ed.), International Encyclopedia of the Sociology of Education.

Marker, P. M. (2003). Another brick in the wall: High stakes testing in teacher education The California Teacher Performance Assessment. Workplace 5.2. Retrieved on March 27, 2004, from http://www.louisville.edu/journal/workplace/issue5p2/marker.html

Nelson, T. (2003). In response to increasing state and national control over the teacher education profession. Teacher Education Quarterly, 30(1), 3-8.

Pritchard, I.A. (2002). Travelers and trolls: Practitioner research and institutional review boards. Educational Researcher, 31(3), 3-13.

Paige, R. (2002). An overview of America's education agenda. Phi Delta Kappan, 83(9), 708-713.

Rowling, J. K. (2000). Harry Potter and the goblet of fire. New York: Scholastic Press.

Sleeter, C. (2003). Reform and control: An analysis of SB 2042. Teacher Education Quarterly, $30(1), 19-30$.

Toch, T. (2000). "Comments on Julia Koppich's 'The Federal role in teacher professional development.'” In Diane Ravitch (Ed.), Brookings Papers on Education Policy 2000_(pp. 265-305). Washington, DC: Brookings Institution Press.

Wolcott, H. (1988). Ethnographic research in education. In R.M. Jaeger (Ed.), Complementary methods for research in education (pp. 187-210). Washington, DC: American Educational Research Association.

Wood, G. (1992). Schools that work: America's most innovative public education programs. New York: Plume.

JOHN KORNFELD is Professor and Director of Graduate Studies in the School of Education at Sonoma State University. His research in curriculum, children's literature, school/university collaboration, and the politics of schooling has been published in such journals as Theory into Practice, Teacher Education Quarterly, and Theory and Research in Social Education. His recent publications include "Framing the conversation: Social studies education and the neoconservative agenda" in The Social Studies, and "Envisioning possibility: Schooling and student agency in children's and young adult literature" in Children's Literature in Education.

KAREN GRADY is an Associate Professor in the Department of Curriculum Studies and Secondary Education at Sonoma State 
University. She has published in the areas of textual politics, adolescent literacies and the schooling of linguistically diverse students in the TESOL Journal, The International Journal of Social Education, and in Education, Policy and the Politics of Identity in the New Latino Diaspora edited by S. Wortham, E. Hamann, \& E. Murillo.

PERRY M. MARKER is Professor and Chair of the Department of Curriculum Studies and Secondary Education at Sonoma State University. He has made presentations at international, national and state education conferences, and has written numerous articles related to curriculum studies that have appeared in journals such as Teacher Education Quarterly, The Social Studies, and Theory and Research in Social Education. Most recently, he has contributed two chapters to the Defending Public Schools series edited by E. W. Ross, Kevin Vinson and Katharine Kesson. His current research interests are in the application of future studies to social studies curriculum, and the standards movement in education.

MARTHA RAPP RUDDELL is recently retired Dean of the School of Education and Professor of Education in the Department of Curriculum Studies and Secondary Education at Sonoma State University in Rohnert Park, California. She taught in the secondary teaching credential program and the graduate Reading and Language advanced credential and degree programs. Dr. Ruddell is author of numerous articles and books, including the 5th edition of Teaching Content Reading and Writing (Wiley) and articles/book chapters "Literacy Research and Educational Reform: Sorting Through the History and the Myths," (Defending Public Schools, Praeger), and "ruok2dA? (Are you okay today?): Literacy and Literate Contexts in the New Millennium," (Wisconsin Reading Association Journal). Dr. Ruddell is Past President of the National Reading Conference, an international educational organization devoted to research in language and literacy. In 1996, she was inducted into the California Reading Association Reading Hall of Fame, and in 2003 she was honored with the Albert J. Kingston Service Award of the National Reading Conference. 